\title{
Chapter 15 SDG 15: Life on Land - The Central Role of Forests in Sustainable Development
}

Jeffrey Sayer*, Douglas Sheil, Glenn Galloway, Rebecca A. Riggs, Gavyn Mewett, Kenneth G. MacDicken, Bas Arts, Agni K. Boedhihartono, James Langston and David P. Edwards

\section{Key Points}

- There will be trade-offs between SDG 15 and other SDGs resulting from competition for land, but there are also synergies and opportunities.

- The principal opportunity of SDG 15 is that it will be recognised and integrated, along with the other SDGs, in all developments.

- The main risk is that short-term priorities and a 'business as usual' approach will undermine this opportunity for integration and synergy and SDG 15 will often be overlooked.

- The scale, and complexity, of challenges for conserving life on land, versus the limited resources available, pose many challenges.

- Greater cross-sectoral integration, not just sectoral policy reform, is essential to advancing SDG 15.

- We encourage conservation and development professionals to engage with those responsible for all the Agenda 2030 targets to ensure that SDG 15 is a priority in all SDG related processes.

\subsection{Introduction}

The claim that stewardship of terrestrial ecosystems, particularly forests and their rich biodiversity, is essential for sustainable development has achieved broad recognition. The conservation of life on land is recognised as Goal 15 of the 17 Sustainable Development Goals (SDGs). When the SDGs were adopted by the UN in 2015, all indicators showed that life on Earth was in decline (Schipper et al. 2008, Tittensor et al. 2014), eroding the ability to meet human needs (Pimm et al. 2014). SDG 15 asks for the protection, restoration and sustainable use of terrestrial ecosystems along

\footnotetext{
* Lead author.
} 
with the sustainable management of forests, combating desertification, halting and reversing land degradation and halting biodiversity loss. Clearly, the pressures of population growth, economic development and increased consumption will only intensify the challenges for the maintenance of life on land. In this chapter we examine the opportunities and challenges that merit particular attention if we are serious about SDG 15 and reversing the decline of life on Earth. In principle, SDG 15 (Life on Land) is recognised as having equal prominence alongside other SDGs. As there are widespread calls for integration and explicit attention to synergies and trade-offs among SDG outcomes (Le Blanc 2015, Stafford-Smith et al. 2017), the existence of SDG 15 should result in conservation concerns and issues having a raised profile within the wider decision-making community. Unfortunately, this appears far from assured. Many people, especially in the biodiverse tropics, view conservation as a concern of rich Western nations with little relevance to immediate local needs. Western conservation agencies that focus on charismatic species and the concerns and preferences of Western audiences do little to dispel these preconceptions (Meijaard and Sheil 2008). At the same time, most people worldwide, including most politicians, policymakers and experts, now live in cities, where they are disconnected from nature and forests (Soga et al. 2016). A recent survey by Price Waterhouse Coopers found that in many countries SDG 15 and SDG 14 (Life below Water) are getting less attention than other SDGs (Scott and McGill 2018). Development and conservation are viewed as being in competition - and development is the more immediate priority.

This chapter summarises recent forest and biodiversity trends and the diverse contexts in which progress towards SDG 15 will play out. We focus on the factors and conditions likely to influence achievement of the goals and targets. We then examine three broad areas: (1) forest cover and management, (2) biodiversity and (3) financial and policy instruments. We examine the implementation of SDG 15 in Indonesia, where challenges over forest and natural resource stewardship will influence the attainment of all SDGs. We advocate a more inclusive, proactive and outcome-based approach to SDG 15, firmly rooted in realistic scenarios. We hope to see transformational change rather than business as usual. (See Table 15.1 for SDG 15 targets and indicators.) 
Table 15.1 SDG 15 Goal, targets and indicators

SDG 15: Protect, restore and promote sustainable use of terrestrial ecosystems, sustainably manage forests, combat desertification, and halt and reverse land degradation and halt biodiversity loss

\begin{tabular}{l|l} 
Targets & Indicators
\end{tabular}

15.1 By 2020, ensure the conservation, restoration and sustainable use of terrestrial and inland freshwater ecosystems and their services, in particular forests, wetlands, mountains and drylands, in line with obligations under international agreements

15.2 By 2020, promote the implementation of sustainable management of all types of forests, halt deforestation, restore degraded forests and substantially increase afforestation and reforestation globally

15.3 By 2030, combat desertification, restore degraded land and soil, including land affected by desertification, drought and floods, and strive to achieve a land degradation-neutral world

15.4 By 2030, ensure the conservation of mountain ecosystems, including their biodiversity, in order to enhance their capacity to provide benefits that are essential for sustainable development

15.1.1 Forest area as a proportion of total land area

15.1.2 Proportion of important sites for terrestrial and freshwater biodiversity that are covered by protected areas, by ecosystem type

15.2.1 Progress towards sustainable forest management

15.3.1 Proportion of land that is degraded over total land area

15.4.1 Coverage by protected areas of important sites for mountain biodiversity

15.4.2 Mountain Green Cover Index

15.5.1 Red List Index

15.5 Take urgent and significant action to reduce the degradation of natural habitats, halt the loss of biodiversity and, by 2020, protect and prevent the extinction of threatened species 
15.6 Promote fair and equitable sharing of the benefits arising from the utilisation of genetic resources and promote appropriate access to such resources, as internationally agreed

15.7 Take urgent action to end poaching and trafficking of protected species of flora and fauna and address both demand and supply of illegal wildlife products

15.8 By 2020, introduce measures to prevent the introduction and significantly reduce the impact of invasive alien species on land and water ecosystems and control or eradicate the priority species

15.9 By 2020, integrate ecosystem and biodiversity values into national and local planning, development processes, poverty reduction strategies and accounts

15.A Mobilise and significantly increase financial resources from all sources to conserve and sustainably use biodiversity and ecosystems

15.B Mobilise significant resources from all sources and at all levels to finance sustainable forest management and provide adequate incentives to developing countries to advance such management, including for conservation and reforestation

15.C Enhance global support for efforts to combat poaching and trafficking of protected species, including by increasing the capacity of local communities to pursue sustainable livelihood opportunities
15.6.1 Number of countries that have adopted legislative, administrative and policy frameworks to ensure fair and equitable sharing of benefits

15.7.1 Proportion of traded wildlife that was poached or illicitly trafficked

15.8.1 Proportion of countries adopting relevant national legislation and adequately resourcing the prevention or control of invasive alien species

15.9.1 Progress towards national targets established in accordance with Aichi Biodiversity Target 2 of the Strategic Plan for Biodiversity 2011-2020

15.A.1 Official development assistance and public expenditure on conservation and sustainable use of biodiversity and ecosystems

15.B.1 Official development assistance and public expenditure on conservation and sustainable use of biodiversity and ecosystems

15.C.1 Proportion of traded wildlife that was poached or illicitly trafficked

Source: https://sustainabledevelopment.un.org/sdg15 


\subsection{Trends and Contexts}

SDG 15 endorses priorities already established through previous conventions and agreements, such as the Convention on Biological Diversity (CBD) and its Aichi Biodiversity Targets and Nagoya Protocol, the UN Convention to Combat Desertification and the Convention on International Trade in Endangered Species. Most SDG 15 indicators draw on existing data and measures. This is potentially both a strength and a weakness. Using existing metrics allows for long-term analysis but runs the danger of perpetuating business as usual and not encouraging attention to emerging needs (see Steffen et al. 2015).

\subsubsection{Forest Cover and Management}

Forest cover and condition are influenced by various drivers - direct and indirect. A growing population, trending towards 9 billion, is increasing demand for food and other commodities and placing more pressure on land while also affecting livelihoods and health. Climate change may curtail food production in some locations and create new options in others (Lobell et al. 2011). Competing demands on land require the management of trade-offs, which will raise many challenges (Laurance et al. 2013). Achieving SDG 15 will require addressing these drivers and trade-offs so as to bolster life on land and accommodate wider societal values.

Many studies document trends and changes in the extent and condition of the world's forests and biodiversity (FAO 2010, 2012, Keenan et al. 2015, Sloan and Sayer 2015). For example, FAO's Forest Resources Assessments have found that between 1990 and 2015, global forest cover decreased by 3.1 per cent, to 30.6 per cent of global land area. Total forest area declined from more than 4.1 billion ha to below 4 billion ha. The rate of loss has slowed since 2010, but there are significant regional variations. From 2010 to 2015, boreal and subtropical forests suffered virtually no net loss while temperate forests gained over 2 million ha per year. Deforestation remained higher in the tropics, with 5-6 million ha lost annually in the same period, a reduction from nearly 10 million ha per year in the 1990-2000 period (FAO 2015).

Using different definitions and methods, Global Forest Watch (2019) shows continued, if uneven, decline in tropical tree cover since 2001. Agriculture has been responsible for about 80 per cent of tropical and subtropical deforestation (Kissinger et al. 2012). Over this same period, large-scale commercial agriculture has replaced subsistence agriculture as the most important driver of change across the tropics and subtropics. In recent years commercial agriculture has been responsible for 70 per cent of deforestation in Latin America, compared to 30-35 per cent in tropical Asia and Africa (Kissinger et al. 2012). 
In recent years the FAO's FRA studies have reported on changes in the condition, management and production of forests (FAO 2012). Though forest area has increased in many parts of the world, much of this is a result of expansion of industrial tree plantations. Planted forest area increased in all regions between 1990 and 2015, while natural forest area declined in all regions except Europe and Oceania (FAO 2015). Plantations constitute about 7 per cent of the world's forests (FAO 2015) and will likely continue to expand beyond 2030.

Another trend concerns sources of wood and timber. The area of timberproduction forest in low-income countries is declining, though it remains stable in higher-income countries. Meanwhile, the volume of wood harvested is increasing in every region except Europe and North America (FAO 2015). Addressing growing demand for wood in the tropics may ultimately require more intensive forest management or greater timber imports from temperate and boreal forests.

\subsubsection{Biodiversity}

Current global species extinction rates are estimated to be about three orders of magnitude above those of the prehuman world (Pimm et al. 2014). Habitat loss, unsustainable hunting, introduced invasive species and other factors have contributed to 322 recorded extinctions of terrestrial vertebrates since 1500. Meanwhile, the populations of most remaining species have declined (Dirzo et al. 2014, Pimm et al. 2014). Detailed assessments by the International Union for Conservation of Nature (IUCN) have identified 24307 species that are currently facing significant threat of extinction (IUCN 2019).

Forests, in particular tropical forests, harbour most of Earth's species and most of the threatened species (Vira et al. 2015). In IUCN's most recent global assessment of mammal species, 25 per cent (1139) were judged 'threatened with extinction' while another 15 per cent (836) were 'data deficient' (Pimm et al. 2014, Schipper et al. 2008). These figures are underestimates, as we still know little about the overall diversity of many tropical taxa. New species are still being discovered in even the best-known groups; for example, 85 new primates were described between 2000 and 2016 (Estrada et al. 2017) and a new great ape (an orangutan, Pongo tapanuliensis) was described in 2017 (Nater et al. 2017).

The risk of species loss reflects multiple factors - including habitat loss, modification and fragmentation, over-exploitation, interactions with other species and climate change - and combinations of all these factors (Selwood et al. 2015). When a species is lost from a forest, the ecological processes that depend upon that species are lost with it; this reduces community resilience and can provoke further species losses (Dirzo et al. 2014, Redford 1992). 
These threats and changes are ongoing worldwide. For example, terrestrial ecosystems are increasingly fragmented by infrastructure (Laurance et al. 2014), posing new challenges for those seeking to protect life on land. Climate change is a major emerging threat. The Intergovernmental Panel on Climate Change (IPCC) shows that the Earth warmed by an estimated $0.74^{\circ} \mathrm{C}$ over the last century and is forecast to warm by another $1.5-4.5^{\circ} \mathrm{C}$ this century (IPCC 2013). Places where forest can grow, and in which species can persist, will change as climate changes. While the worst impacts likely lie beyond 2030, significant changes are now underway. Various local extinctions have already been attributed to changes in climate (Cahill et al. 2013, Wiens 2016,). Predicted changes mean that many species will not persist unless they move to more favourable locations, but many species face barriers to such movement or appear unable to move rapidly enough to find and track suitable climates (Corlett and Westcott 2013). Even common species appear at risk (Warren et al. 2013). While outcomes remain uncertain, many authoritative accounts based on IPCC scenarios anticipate numerous extinctions (Cahill et al. 2013). Even if forests persist, climate will influence their growth and productivity and intensify threats, such as drought and fire that impact their ecological and economic viability.

\subsubsection{Social-Economic Systems}

For several billion people, wild plants and animals remain essential elements of daily life. Forests and biodiversity underpin subsistence, providing goods and services important for health, fuel and income. Many farmers still depend on wild resources. Food security and nutrition are bolstered and sustained by wild species to a much greater extent than is often widely recognised (Colfer et al. 2006). Many million people lack ready access to modern healthcare and depend on wild plants and animals for medicines. Forest-dependent people are among the world's poorest and most marginalised. In many cases, wild resources provide a crucial safety net, allowing people to find food and manage after crises (Liswanti et al. 2011). As these dependent populations grow and access to wild resources declines, there will be major implications for people's lives and livelihoods. If these wild resources are no longer available, difficult lives will be made even harder.

As challenges to development and sustainability become increasingly evident (climate change, water, food security, inequality etc.), bottom-up commitments may be stronger drivers of change than top-down discourses and policy. SDG 15 conveys a sense that central government is the predominant driver of moves to conserve life on land, but recent practice suggests that in many countries moves to achieve conservation through decentralised 
governance systems are gaining traction (Agrawal et al. 2008, Ribot et al. 2006). Decentralised and community resource management are being pursued in many countries and in diverse contexts, but they are not always the panacea that their advocates claim (Agrawal and Gibson 1999, Boedhihartono 2017, Robinson et al. 2014). Some communities that have maintained strong control over their lands and resources remain effective in achieving desirable conservation outcomes and are willing to see large tracts of land set aside in perpetuity: an example is the protection of Papua's Foja Mountains and large areas of the Mamberamo Valley that are held to be sacred (Sheil et al. 2015). Nonetheless, in many cases there is a tension between the management of resources for local goals and the need to conserve public goods values (Sayer et al. 2017).

The growth of economies, a major target of many other SDGs, will have major impacts on terrestrial biodiversity. Human populations will move, cities will grow, agricultural technologies will allow for producing more on less land (Sayer and Cassman 2013). If these trends continue, the supply and demand of forest goods and services in 2030 and beyond will be primarily determined by indirect drivers outside the forest sector (Bruinsma 2009). The planet as a whole may be advancing through a forest transition in which nations experience a period of protracted forest loss, followed by reaching a low point and then a stage of widespread reforestation and forest recovery (Rudel et al. 2005). Different regions are advancing at different speeds, with some areas still suffering dramatic forest loss, such as Southeast Asia, and others showing substantial gain, such as the tropical Andes. Those who seek to implement SDG 15 need to do so with these likely changes in mind. Maintaining forestdependent biodiversity through the low point in the transition, and the rapid expansion of suitable habitat in the post-transition era, will be important (see Wright and Muller-Landau 2006 and subsequent discussions, e.g. Melo et al. 2013, Rudel et al. 2009). Examples include the widespread protection even of young or degraded forests and control of damaging practices such as hunting, over-exploitation and fire that may reduce the conservation value of human impacted forests (Chazdon et al. 2009). The implication is that there are many domains where policymakers can make a major difference to the maintenance or loss of life on land. Those seeking to address SDG 15 should identify the right policy signals to ensure the best outcomes for biodiversity and for societies' future needs. These are long-term objectives: 2030 should not be seen as an end point - the changes that are under way in 2030 will influence life on land for millennia.

Aside from the many sectoral challenges, those addressing SDG 15 will also confront long-standing issues of legal enforcement. Consider the challenges posed by the illegal trade in wildlife and timber - worth, respectively, an 
estimated USD 8-10 billion (Haken 2011) and USD 7 billion per year - with links to powerful organised crime systems and insurgencies (Milner-Gulland 2018). In many regions military interests manage and protect these activities. Trends suggest that 'regulatory approaches are being overwhelmed by rising prices and growing relative poverty between areas of supply and centers of demand. Aggressive enforcement of trade controls, in particular bans, can increase profits for traffickers and lead to the involvement of organized criminals with the capacity to operate even under increased enforcement effort' (Challender and MacMillan 2014: 484). Foresters, conservationists and enforcement agencies are ill-equipped to confront such forces. More light needs to be shed on these issues, which will prove challenging. According to Global Witness, in 2016 there were 200 confirmed murders of environmental activists, wildlife rangers and Indigenous leaders trying to protect their land (Watts and Vidal 2017).

\subsubsection{What Are the Future Challenges for Conservation of Life on Land?}

What challenges will forests and biodiversity face in the coming decade? How will the context of conservation and sustainable use change from that which existed in 2015? How will progress on the other SDGs impact the attainment of SDG 15? Several major trends are already apparent, all of which will impact on life on land. If economies continue to grow as they have in recent decades, then many more people will escape from extreme poverty - including many who currently depend upon forest resources for their livelihoods. The dependency of these people on forests will decrease. If economies stagnate, then the rural poor will suffer disproportionately and achieving conservation goals will be more difficult. Under optimistic scenarios, people in rural areas will have better health and education and, consequently, smaller families. The ability to provide services, peace and opportunities to those who survive in and around forests, rangelands and wetlands will be a major determinant of many of the SDGs, including SDG 15. A major unknown is the fate of the 2 billion-plus subsistence farmers in the tropics: will economies and education provide attractive alternative livelihoods on or off the lands? If progress is made on the other SDGs, then we see the following scenario unfolding between now and 2030:

- People will move from rural areas to cities.

- Agriculture will continue to intensify and move towards larger, more mechanised farms. Industrial agriculture, especially tree crops, will continue to expand into forested areas. Productivity gains may reduce demand for land, but in some regions expansion may displace farmers into other frontier areas (Laurance et al. 2013). 
- A shift will occur in the demand for agricultural commodities - for example an increase in meat and dairy consumption - as peoples' purchasing power increases.

- Infrastructure will continue to expand into forest areas to access mineral resources and new land for agriculture.

- Demand for near-natural forests for their biodiversity values and other ecosystem services will increase. Demand for forests for recreational use, especially in peri-urban areas, will also grow (Tyrväinen et al. 2005).

- Processes of decentralisation of natural resources management to communities and local governments will continue. Integrated management practices may become more widely adopted.

- Countries will move towards a green economy or bio-economy and increasing forest extent and health will be supported by this trend.

- Timber harvesting from natural forests will continue to decline as more timber is produced at less cost from plantations, on farms and along roadsides.

- Capacity to assess and monitor a wide range of forest attributes, particularly with improved remote sensing and application of the 'internet of things', will increase.

- Attempts to address some of the world's climate concerns through forest conservation and restoration will intensify.

- Climate-related stresses on forests and the associated risks from fire and invasive species will intensify.

The SDGs are part of a greater process. The SDGs will not be entirely met by 2030 , with inevitable disparity in the progress made in different countries. Conserving life on land will remain a work in progress and SDG 15 will play out in a variety of contexts. Contexts will strongly influence the approaches that would be appropriate to pursue SDG 15 targets. Those implementing the SDGs will need the awareness, flexibility and understanding to adapt to the nuances and opportunities of their specific situations.

\subsection{Achieving SDG 15 Targets}

\subsubsection{Targets for Forest Cover and Management}

The measurement and interpretation of forest resource changes is challenging. Even measuring changes in forest area remains beyond the capacity of many countries - though increasingly easy access to satellite-based imagery 
is helping address this. For example, Terra-i ${ }^{1}$ and Global Forest Watch ${ }^{2}$ both provide access to land-cover data. FAO's FRA already collects data applicable to SDG 15 - including forest area as a proportion of land area and country compliance with requirements to report on policies relevant to sustainable forest management. The FRA also reinforces concerns about SDG 15. Forest area change means different things to different countries. For many forestrich tropical countries, economic growth is seen as requiring increased forest conversion to agriculture and other uses. A case in point is Bolivia, which in its submission to the FAO Forest Resources assessment for 2015 stated the intention to reduce forest area by some 75 per cent, presumably in order to spur economic growth. This demonstrates the conundrum governments face in planning forest area. Many governments will choose the path of economic growth over forest conservation, but they seldom make this de facto policy explicit.

Indicator 15.2.1 requires measurement of progress towards sustainable forest management. What defines and determines sustainable forest management remains unclear for many. The topic is contentious, and achievements are difficult to quantify. This is demonstrated in how the FRA has handled the topic since FRA 2010. In the 2010 reporting year, countries were simply asked how much forest area was under sustainable forest management. Guidelines were lacking and the reported values were not taken seriously outside the FAO process. In the most recent FRA (FAO 2015), countries were asked to report a range of values including areas under management plans - inclusive of those that had community inputs, monitoring of management plans and public forest resource reporting (MacDicken 2015). This approach allows users to select indicators that best fit their understanding of sustainable forest management. It is a pragmatic solution, but there are still concerns that the selected indicators neglect crucial factors such as the contributions of forests - and how they are managed - to people.

By focusing on forest cover and protected forest extent, SDG 15 may underestimate the complexity of forest land governance and the differing values of forest types. Forests where timber has been harvested often retain significant biodiversity values and protecting these values is important, especially when the other option is forest clearance (Edwards et al. 2014). For centuries, tropical foresters sought to protect and manage natural forests in a sustainable manner (Dawkins and Philip 1998, Ghazoul and Sheil 2010, Wiersum 1995). Forestry's destructive image arose in the second half of the twentieth century when large-scale industrial timber harvesting was widely promoted

\footnotetext{
1 www.terra-i.org

2 www.globalforestwatch.org/
} 
without regard for sustainability. Nonetheless, though overshadowed, efforts to protect and sustainably harvest tropical forests have continued into the modern era. Two large tropic-wide meta-analyses found that selectively harvested production forests retain a species richness of animals, insects and plants similar to that found in undisturbed forests (Gibson et al. 2011, Putz et al. 2012), and far higher species richness than competing non-forestland uses (Gibson et al. 2011). Production forests also harbour an array of IUCN redlisted species (Edwards et al. 2010), underscoring their potential to protect critical biodiversity. Managed timber concessions are often better protected than poorly staffed protected areas (Meijaard and Sheil 2007). However, harvesting timber at higher intensities (Burivalova et al. 2014), failing to retain patches of undisturbed forest within production landscapes (Edwards et al. 2014) or using more destructive conventional rather than reduced-impact logging techniques (Bicknell et al. 2015) devalues the conservation potential of production forests. Intensively managed tropical forests tend to lose certain species and become more homogeneous (Alroy 2017).

Production forests should be seen as an addition to rather than a replacement for more strictly protected areas. While there are many uncertainties and unknowns, when we look at the big picture we do largely know which practices improve conservation outcomes (Dale et al. 2000, IUCN and ITTO 2019, Meijaard et al. 2005). Achieving SDG 15 requires an open-minded approach that seeks opportunities to promote improved conservation outcomes not only through the protection of large-scale intact landscapes devoid of people, but also through the small-scale trade-offs that arise in more densely settled regions.

\subsubsection{Targets for Biodiversity}

Achieving SDG 15 requires an intensification of efforts to implement the Aichi Biodiversity Targets and a range of other plans and strategies elaborated by intergovernmental processes. The Aichi targets encompass more ambitious goals than those originally agreed on by the CBD in 2002. Available data from the 55 different biodiversity indicators compiled by the World Conservation Monitoring Centre suggest that the Aichi targets, set by the CBD in 2010, will not be achieved by the 2020 target date (Tittensor et al. 2014). By 2010, 31 indicators had not been achieved and biodiversity was still declining with no substantial reductions in the rate of loss. Pressures on biodiversity were still increasing. There were some successes, including improvements in the nominal coverage of protected areas (Butchart et al. 2010), but most of the increase was in protected landscapes whose biodiversity values may not be high. 
By 2016, some 14.7 per cent of the world's terrestrial surface was officially protected (217 155 areas): coverage is generally higher in the tropics (Brooks et al. 2009). Yet, as protected area targets are often achieved at the cost of reduced management standards and abilities, this alone is not a sufficient proxy for improved biodiversity outcomes (Dudley et al. 2016, Watson et al. 2014,). Many species occur primarily, or exclusively, outside formal protected areas or require much larger habitat areas to ensure viability (Brooks et al. 2009, Ricketts et al. 2005, Rodrigues et al. 2004). This reflects the tendency for governments to protect areas that are economically marginal and under only limited threat. Such approaches do not yield the best conservation outcomes. Protected areas are effective only if adequately resourced, yet this is often not the case (Brooks et al. 2009, Bruner et al. 2001, Inamdar et al. 1999). These shortfalls in funding tend to be most severe in the poorest countries - the places where investments in conservation can likely make the biggest direct contributions. A simple national-scale conservation-status index based on changes in the IUCN red-listing of birds and mammals can predict with remarkable accuracy the positive impacts of the financial investments made towards achieving conservation versus benefits from economic, agricultural and population growth (Waldron et al. 2017). This model indicates that the relative benefits of conservation spending are greatest in the poorest, most biodiverse nations (Waldron et al. 2017).

McCarthy et al. (2012) examined global conservation needs and estimated that the conservation of terrestrial species would require an annual expenditure of USD 76.1 billion, equivalent to 0.1 per cent of global GDP, or less than 5 per cent of global defence spending (Sheil 2017). Current expenditures average about half of these requirements in higher-income countries and less than one-third (31 per cent) in lower-income countries. While McCarthy et al. (2012) are doubtless correct that conservation should obtain increased financial support, their approach neglects local costs and consequences (Sheil et al. 2013), including past injustices, widespread evictions and mistreatment of local populations (Agrawal and Redford 2009, Dowie 2011). These are not just a 'colonial legacy'; many communities living near protected areas suffer from the presence of wild animals: crops are destroyed, domestic animals are killed and people are attacked (Hill 2015, Naughton-Treves et al. 2011). With current laws often not offering any provisions for direct compensation, victims bear the costs.

Such human costs of protected areas matter both as an ethical concern in their own right, not least because they can erode advances being made on other SDGs such as ending poverty (SDG 1), access to affordable energy (SDG 7) and justice (SDG 16), and because they undermine community support and escalate threats. They pose a challenge to local support for conservation (Sheil et 
al. 2013). Indeed, failure to satisfactorily address such costs and concerns has often turned communities against conservation (Baker et al. 2012, Boissière et al. 2009, Sharpe 1998, Temudo 2012), with much conservation expenditure required to counter the ensuing conflicts (Roe 2008). We already see politicians speaking against conservation and promising that if they are elected, they will ensure that people will get their lands back (Sassen et al. 2013). In a world in which conservation requires societal support, the manner in which local costs are dealt with appears crucial. While the biophysical measures of SDG 15 do not address these trends and their drivers, those looking to achieve these goals should.

\subsubsection{Targets for Financial and Policy Instruments}

The SDG 15 targets related to governance, particularly Targets 15.9-15.12, cover policy integration, resource mobilisation and capacity-building for the conservation, sustainable use and fair and equitable sharing of benefits from forests, biodiversity and landscapes. Of these, the call for policy integration is the most innovative. Indeed, the loss of terrestrial biodiversity is favoured by existing sectoral approaches that underlie land-use decisions and their hierarchical ordering. Mining and infrastructure are higher priorities than agriculture, which in turn is higher than forestry and conservation. Integrating biodiversity concerns into all land-use policies and decisions would be an advance. Thus, agriculture, infrastructure and forestry could become much more nature-inclusive, which might then substantially reduce their impacts on biodiversity. The absence of reference to natural resource issues in most of the SDGs is symptomatic of a fundamental trade-off among the priorities of the different sectors.

The advancement of nature-inclusive land-use policies will in many cases be opposed by vested interests. The decisions that drive the political economies of biodiversity loss and deforestation, including illegal practices and organised crime, are shaped by these economic-interests. Greater cross-sectoral integration, not just sectoral policy reform, is essential. Transformational change of political economies is surely essential, but such change appears unlikely. Along with policy changes, the behaviour of producers and consumers needs to be fundamentally changed. Working with the best integrative practices at the landscape level can be a first step forward (Sayer et al. 2013).

The other two institutional targets under SDG 15 are resource mobilisation and capacity-building. External forest finance has relatively little impact in most cases because the value of forest production or alternative land uses is typically much higher than development assistance funding. Simula (2008) provided an estimate of total official development assistance (ODA) to the forest sector at nearly USD 2 billion per year, of which about USD 1.3 billion 
is to forestry and some USD 700 million to forest conservation. In contrast, wood removals from tropical Africa, Asia, Oceania and South America were reported to be approximately $1803 \times 10^{9}$ cubic metres in 2011. Using a 2011 value of USD 150 per cubic metre this comes to about USD 270 billion, or more than 100 times the value of total official ODA flows to forests. ${ }^{3}$ Simula's estimate of USD 1.3 billion of ODA to forestry is less than 0.5 per cent of estimated value of wood production. This does not include the value of nontimber forest products, or the value of domestic public-sector expenditure. In addition to external ODA flows, Whiteman et al. (2015) report some USD 7.3 billion in public-sector forest expenditure in tropical and subtropical countries in 2010. As another comparison, consider palm oil: in 2016, the value of Indonesian palm oil exports was USD 18.1 billion (GAPKI 2017). The financial drivers impacting forestlands are vastly larger than government allocations to the forest sector. ODA contributions to the forest sector remain important to support research and to provide examples of sustainable forestry, but many of the problems of unsustainable resource use will only be resolved with widespread changes in the behaviour of both producers and consumers and their governments.

\subsection{SDG 15 in Indonesia: A Case in Point}

Indonesia is a major player in the SDG process. President Susilo Bambang Yudhiono was co-chair of the UN committee that developed the SDGs. Indonesia is striving to be a leader in the pursuit of the SDG concept.

Indonesia officially classes 91 million ha (49.8 per cent of its land area) to forest. However, much of this land is no longer forested, and there are multiple overlapping claims on the land. Government figures state a net annual loss of forest of 0.7 per cent from 2010 to 2015 (684 000 ha) (FAO 2015). Relatively intact old-growth forests represent at most 50 per cent of total forest area and are stated to be declining by 800000 ha per year. Much deforestation occurs in areas previously degraded by swidden agriculture or logging, in lowland areas, although recently some expansion of deforestation has occurred in the uplands (Margono et al. 2014). Approximately 45 per cent of recent deforestation has occurred within industrial concessions, mainly for oil palm (Abood et al. 2015).

Indonesia is home to 10 per cent of the world's flowering plant species, of which 55 per cent are endemic; 12 per cent of mammal species; 17 per cent

\footnotetext{
${ }^{3}$ Calculated based on ITTO Market Report December 2011 prices with an unweighted approximation of USD 100 per cubic metre of domestic logs and USD 200 per cubic metre of export logs.
} 
of bird species; 16 per cent of reptile species; and 35 per cent of primate species (CBD Secretariat 2018). Habitat loss, deforestation, fragmentation and degradation means that 1259 species are threatened. This is despite protected areas covering 15 per cent of total sea and land area (von Rintelen et al. 2017) and 41 per cent of forests (Abood et al. 2015). Lowland forests contain the most biodiversity, but are the most threatened due to increasing pressure from population growth, infrastructure development, fires and conversion to industrial estate crops (CBD Secretariat 2018).

As an emerging economy, development in Indonesia is rapidly expanding into areas rich in terrestrial and marine biodiversity. About 10 per cent of Indonesians live below the national poverty line, a figure in annual decline. Population growth means that average farm size is becoming smaller (McCarthy and Robinson 2016). Human development in the eastern provinces lags behind the islands closer to the administrative centre. Government investments in infrastructure to improve the lives of the poorest provinces, such as West Papua and Maluku, will increase the pressure on forests as access becomes easier for extractive industries. Some 50-70 million Indonesians have self-identified as 'Indigenous', and many of these people rely on natural resources for their livelihoods (AMAN 2013). Many Indigenous Indonesians, particularly those living in forests without legal rights, are among those most affected by forest degradation and loss. Integration of forest policy decisions with local realities is increasing, and the government is working towards recognising the rights of Indonesia's rural poor, particularly the Indigenous forest-dependent peoples.

Decisions on use of forestlands lie with the Ministry of Environment and Forestry (MoEF). Indonesia's constitution acknowledges the concept of traditional ownership, but also declares that the state has responsibility for the nation's natural resources (Wrangham 2002). This ambiguity permitted post-independence governments to assert ever-greater control over forest areas, leading to a complex situation where different state institutions have overlapping, and seemingly incompatible, rights and responsibilities for the same lands. For decades, campaigners and others have urged the Indonesian government to return control of forests to local communities. Indonesia's Constitutional Court finally agreed in its decision No. 35/PUU-X/2012. Consequently, President Jokowi pledged that local rights would be respected and that 12.7 million ha of forestland would be returned to communities by 2019. This transfer of rights is continuing, but progress has been slow, inhibited by legislative and political hurdles.

The pledged redistribution of 12.7 million ha of forestland to community and Indigenous groups could significantly contribute to conserving life on land in Indonesia. While most areas will be under community forestry 
schemes, an increasing proportion of forestland will now come under the private ownership of Indigenous groups. Considerable uncertainty remains as to how the behaviour of communities will change in response to these new land-tenure arrangements (Sayer et al. 2017). More than 40 million ha of the forest estate is licenced to concessionaires: 21.49 million ha for timber exploitation and 19.4 million for oil palm plantations (McCarthy and Robinson 2016). These industries drive rural economies and contribute significantly to the national economy. Current investments in the service sector and tourism may reduce economic reliance on natural resource extraction and exports. Agricultural and forestry land-management standards will be critical to maintaining Indonesia's life on land in a future period of economic transition. The tensions between drivers of the globalised economy and the rights of rural and Indigenous populations in Indonesia echo similar tensions in many developing tropical countries.

\subsubsection{SDG Implementation in Indonesia}

The SDGs in Indonesia are overseen by an SDG coordination team (Figure 15.1) that integrates targets and indicators within the medium-term plans of central and provincial governments. The national SDG action plan is the template for all provincial action plans for the period up until 2020 .

The top-down nature of the SDGs presents challenges for the application of SDG 15 in many countries, including Indonesia. The SDGs prioritised in the national SDG action plan must pass through the national and subnational development plan and budgets before implementation at the local level. In this process, the Indonesian government identifies which goals align

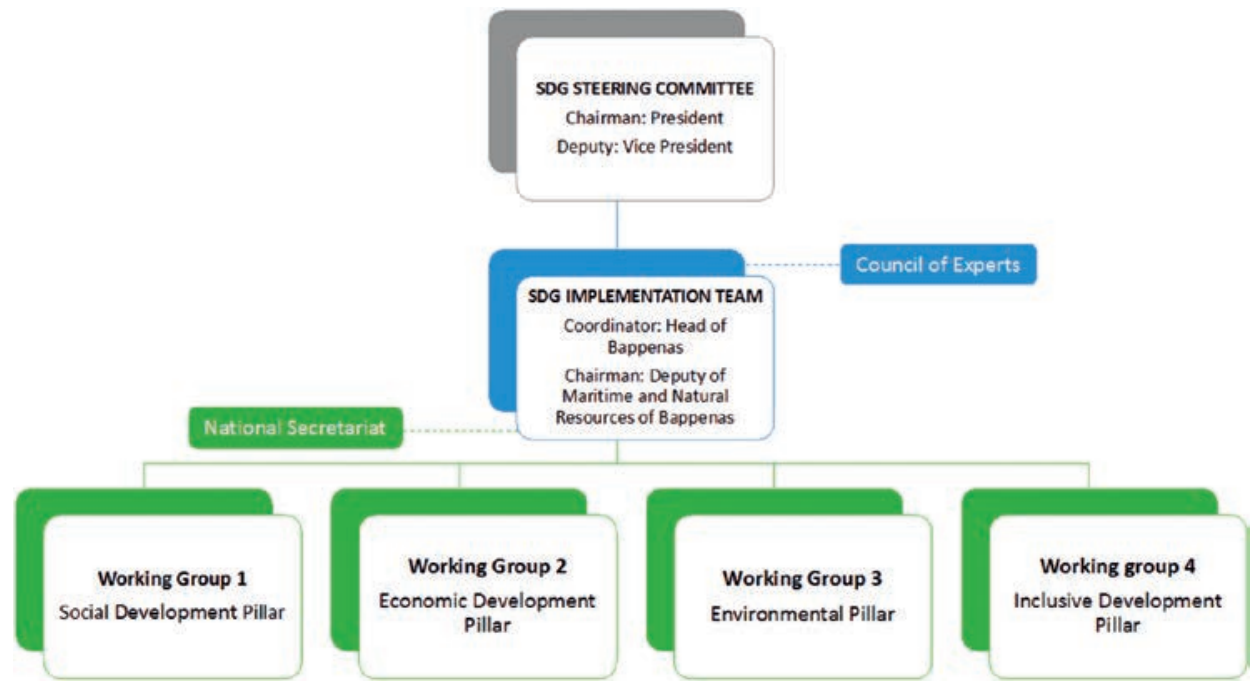

Figure 15.1 Organisational structure of SDG coordination in Indonesia. 
with national and regional priorities and allocates resources towards these priorities. As a result, some SDGs receive higher budget allocations, particularly SDG1 (No Poverty) and SDG2 (Zero Hunger). Targets 15.4, 15.A and 15.B are not identified in the national development plan, so we would expect to see no investment in, for instance, mountain conservation. Considering the trend for increased deforestation in upland areas, the omission of Target 15.4 is a concern for protection of biodiversity and preservation of forested land.

In Riau, the first province to complete its SDG action plan, SDG 15 receives little attention: just three targets - 15.1, 15.2 and 15.3 - are included. Unlike the national SDG action plan, Targets 15.5-15.9 are excluded. For a province that has extensive industrial forestry concessions, it is surprising to see that key biodiversity and invasive species targets are not addressed. An acknowledged value of the SDG process - to encourage integration and to make tradeoffs more explicit - is not being addressed in the Riau Provincial Action Plan. Interestingly, some of the estate crop industries operating in Riau are using the SDGs as a framework for guiding their own activities in ways that promote environmental and social sustainability.

Indonesia is prioritising the SDG Target 15.2 for the restoration of degraded land. The MoEF aims to identify 500000 ha of forest for restoration by 2019, and to have actually restored 100000 ha by that date. The way this is done will have important consequences for other SDGs. In the past, degraded lands have often been allocated for estate crop development. There will still be pressure from local governments to convert degraded land to estate crops in order to drive local economic development. If MoEF restores natural forest, then a significant contribution to SDG 15 could be made. Further expansion of estate crops could lead local communities to lose their land and suffer economically (SDG 1) and culturally (SDG 2 Zero Hunger, SDG 10 Reduced Inequalities). People could be forced to move and could degrade forests in other areas. Estate crop development could provoke land conflicts and run counter to SDG 16 (Peace, Justice and Institutions).

A harmonised approach to the SDGs requires a full understanding of the social-ecological systems where change is happening. The danger is that SDG 15 is only used as a measuring and communication tool, unable to address the myriad of interconnected impacts that result from focusing only on achieving the headline indicator measurements.

\subsubsection{Conclusions for Indonesia}

Indonesia is taking a strong position on implementing the SDGs, but, like many other countries, is challenged to fully understand how the SDGs interact. The establishment of 12.7 million ha of forestlands under community 
management has implications for SDGs $1-3$ and many more, but currently there is no framework for capturing this information and measuring the impacts of such policies on the other SDGs. Government policies tend to favour the pursuit of individual goals and may overlook trade-offs. As in many countries, SDG implementation is the responsibility of sectoral institutions. It is proving difficult to deal with the interconnected web of targets and indicators that Agenda 2030 envisages.

In many cases, the only options for Indonesia's rural population to escape poverty require converting more forestland to agriculture or for people to move to cities. Local and provincial governments are understandably sympathetic to the needs of the rural poor. Reclassification of land as 'other land use' allows more land-clearing by smallholders but also by estate crop companies. Estate crops provide employment, drive local economies and are favoured by local government. The political economy of land-based investments in Indonesia has been widely debated (Barr and Sayer 2012). Lessons learned from REDD+ demonstrate the difficulty of coordinating action against deforestation and greenhouse gas emissions on a national scale. Navigating synergies and trade-offs of SDGs will have to be context-based, recognising that forests in different parts of Indonesia are at different stages of transition. The diversity of Indonesia means SDGs cannot take a one-size-fits-all approach. As tenure arrangements continue to evolve, the challenge of conserving life on land will have to be met in a context of contested land claims and greatly increased pressures on forests. The dilemma facing the achievement of the SDGs in Indonesia is symptomatic of the situation found in many tropical countries under extreme development pressures.

\subsection{Synergies and Trade-offs}

The achievement of SDG 15 will have impacts on and be decided by the other SDGs. Context is everything, and the responsibility for each country to establish national priorities for implementation of the SDGs will determine the extent of synergies and trade-offs.

Life on land constitutes the essential environmental underpinning for human existence, and hence for all other SDGs. The degree to which other goals are given higher priority than SDG 15 will determine the extent of potentially large negative trade-offs. This is obvious when there are competing demands for land: for example, converting forests to agriculture could mean that SDG 2 competes with SDG 15. However, if SDG 2 is achieved through increased agricultural efficiency and more food is produced on less land, then there is potential for a positive synergy. A major potential synergy exists between attainment of SDG 15 and Target 16.6, the development of 
effective institutions. There is an urgent need in many countries to reform the institutions responsible for forests so that they can better deal with the multiple values of forests and the diverse stakeholders concerned by these values. Many other potential synergies with forests and forest biodiversity have an impact on people's lives, such as the maintenance of pollinators required for various crops (IPBES 2016). We know from advances over the past decade that, in many regions, accessible groundwater (Ilstedt et al. 2016) and the maintenance of reliable rainfall depends on forests and tree cover to a much greater degree than most policymakers and their advisors yet realise (Ellison et al. 2017, Sheil 2018). A continuing dialogue around these potential synergies, both among experts and among the general population, would ensure more informed decision-making in which synergies leverage balanced sustainable development to achieve lasting benefits for life on land.

\subsection{Discussion}

SDG 15 is welcome in directing high-level attention to the need for conservation; but without an emphasis on integration, wide political and public engagement and greater responsiveness to local needs, SDG 15 risks perpetuating a sectoral, top-down approach. Decision-makers are now seeking to break down sectoral barriers, develop new institutional arrangements for managing landscapes and focus attention on the underlying causes of ecological decline rather than the symptoms. Integrated approaches to managing life on Earth have been recognised as essential for several decades (Brundtland 1987, IUCN et al. 1980). Many countries are experimenting with decentralised institutions for managing natural resources (Sayer et al. 2005). Experiences gained through these initiatives can create opportunities for further transformation. Integrated, landscape-scale governance arrangements are now being widely pursued (Sayer and Collins 2012). Much of the success of the SDGs will depend on whether SDG 15 encourages or impedes these ongoing changes.

The future of life on Earth depends largely on actions taken in support of all the SDGs. One might expect numerous references to environmental constraints in the indicators for all SDGs, but such references are few: there is only one mention of the word 'forests' in the entire SDG text outside SDG 15, in Target 6.6. Conservation and development are interdependent. Life on land, and forests in particular, is in general being husbanded better in countries that score well on the development indicators included in the other SDGs. Forests continue to decline in poorer countries with weak institutions. The fate of life on land really depends upon progress on SDGs 1-14 and 16-17. 
In the introduction to this chapter we noted that SDG 15 could raise the profile of conservation within the broader community. We also noted the tendency for SDG 15 to be viewed as a second-tier goal behind the others. We must combat this: it is not the intention of Agenda 2030 to select and privilege some SDGs over others. This points to the need for SDG 15 advocates to reach out to those responsible for the other SDGs to show how and where the greatest synergies and most modest trade-offs can be achieved. We need to show that conservation can work with development rather than against it.

Many questions advanced by the conservation and development community over recent years and decades remain contentious. Many of these are central to the advancement of SDG 15. For example, are intensified (landsparing) farming approaches preferable to low intensity (land-sharing) systems (Kremen 2015, Phalan et al. 2011)? We now know the answers depend on circumstances, and the fate of any 'spared land' is key. Continuation of such debates and further technical advances remain necessary to ensure better informed decisions.

\subsection{Conclusions}

If global economies continue to grow and people become more prosperous, then attitudes to forests and biodiversity will change. People may be more receptive to conservation, and moves towards green growth and bio-based economies will alleviate pressures on life on land. If economies stagnate between now and 2030, then the opposite may occur: people will be more concerned about their short-term well-being and may resist conservation measures. These trends may manifest themselves differently in poorer and richer countries. The degree to which SDG 15 and all the other SDGs are attained will be highly dependent on economic, social and political trends from now until 2030.

The targets and goals indicate what Agenda 2030 aspires to achieve, but they do not tell us how to get there. Since progress will be needed in highly divergent local contexts, there is need for the SDG process to be based upon locally learned lessons so that these can feed into SDG and forest policies at higher levels. Many decisions will be taken at the landscape level through a continued process of experimentation and adaptation. Progress in any of the SDG targets may involve fits and starts, setbacks and failures; learning must be an integral part of the agenda. Navigating an optimal path for development in both the short term and the longer term is a major challenge. Integrating SDG 15 into all the processes guided by the other SDGs will be essential to support life on land to 2030 and beyond. 


\section{of References}

Abood, S. A., Ser Huay Lee, J., Burivalova, Z., Garcia-Ulloa, J. and Koh, L. P. 2015. Relative contributions of the logging, fiber, oil palm, and mining industries to forest loss in Indonesia. Conservation Letters 8(1):58-67. doi.org/10.1111/conl.12103.

Agrawal, A., Chhatre, A. and Hardin, R. 2008. Changing governance of the world's forests. Science 320:1460-2.

Agrawal, A. and Gibson, C. 1999. Enchantment and disenchantment: The role of community in natural resource conservation. World Development 27(4):629-49.

Agrawal, A. and Gibson, C. C. 2001. Communities and the environment: ethnicity, gender, and the state in community-based conservation. New Brunswick: Rutgers University Press.

Agrawal, A. and Redford, K. 2009. Conservation and displacement: An overview. Conservation and Society 7(1):1-10.

Alroy, J. 2017. Effects of habitat disturbance on tropical forest biodiversity. Proceedings of the National Academy of Sciences 114:6056-61.

AMAN (Aliansi Masyarakat Adat Nusantara) 2013. Indonesia and the denial of Indigenous peoples' existence. Available at: www.aman.or.id/indonesia-and-the-denial-of-Indigenous-peoplesexistence/ (Accessed 16 February 2019).

Baker, J., Milner-Gulland, E. and Leader-Williams, N. 2012. Park gazettement and integrated conservation and development as factors in community conflict at Bwindi Impenetrable Forest, Uganda. Conservation Biology 26:160-70.

Barr, C. M. and Sayer, J. A. 2012. The political economy of reforestation and forest restoration in Asia-Pacific: Critical issues for REDD+. Biological Conservation 154:9-19.

Bicknell, J. E., Struebig, M. J. and Davies, Z. G. 2015. Reconciling timber extraction with biodiversity conservation in tropical forests using reduced-impact logging. Journal of Applied Ecology 52(2):379-88.

Boedhihartono, A. K. 2017. Can community forests be compatible with biodiversity conservation in Indonesia? Land 6(1):21.

Boissière, M., Sheil, D., Basuki, I., Wan, M. and Le, H. 2009. Can engaging local people's interests reduce forest degradation in Central Vietnam? Biodiversity and Conservation 18(10):2743-57.

Brooks, T. M., Wright, S. J. and Sheil, D. 2009. Evaluating the success of conservation actions in safeguarding tropical forest biodiversity. Conservation Biology 23:1448-57.

Bruinsma, J. 2009. The resource outlook to 2050. Paper presented at Expert Meeting on How to Feed the World. Rome: FAO.

Brundtland, G. H. 1987. Report of the World Commission on Environment and Development: 'Our Common Future'. New York: United Nations.

Bruner, A. G., Gullison, R. E., Rice, R. E. and Da Fonseca, G. A. 2001. Effectiveness of parks in protecting tropical biodiversity. Science 291:125-8.

Burivalova, Z., Şekercioğlu, Ç. H. and Koh, L. P. 2014. Thresholds of logging intensity to maintain tropical forest biodiversity. Current Biology 24(16):1893-8. 
Butchart, S. H., Walpole, M., Collen, B. et al. 2010. Global biodiversity: Indicators of recent declines. Science 328(5982):1164-8.

Cahill, A. E., Aiello-Lammens, M. E., Fisher-Reid, M. C. et al. 2013. How does climate change cause extinction? Proceedings of the Royal Society B: Biological Sciences 280:1-10.

CBD Secretariat 2018. Indonesia Country Profile. Available at: www.cbd.int/countries/profile/ default.shtml?country=id (Accessed 26 January 2019).

Challender, D. W. and Macmillan, D. C. 2014. Poaching is more than an enforcement problem. Conservation Letters 7:484-94.

Chazdon, R. L., Peres, C. A., Dent, D. et al. 2009. The potential for species conservation in tropical secondary forests. Conservation Biology 23:1406-17.

Colfer, C., Sheil, D., Kaimowitz, D. and Kishi, M. 2006. Forests and human health in the tropics: Some important connections. UNASYLVA 57(2):3.

Corlett, R. T. and Westcott, D. A. 2013. Will plant movements keep up with climate change? Trends in Ecology \& Evolution 28:482-8.

Dale, V. H., Brown, S., Haeuber, R. A. et al. 2000. Ecological principles and guidelines for managing the use of land. Ecological Applications 10:639-70.

Dawkins, H. C. and Philip, M. S. 1998. Tropical moist forest silviculture and management: A history of success and failure. New York: CAB International.

Dirzo, R., Young, H. S., Galetti, M. et al. 2014. Defaunation in the Anthropocene. Science 345:401-6.

Dowie, M. 2011. Conservation refugees: The hundred-year conflict between global conservation and native peoples. Cambridge, MA: MIT Press.

Dudley, N., Phillips, A., Amend, T., Brown, J. and Stolton, S. 2016. Evidence for biodiversity conservation in protected landscapes. Land 5(4):38.

Edwards, D. P., Larsen, T. H., Docherty, T. D. et al. 2010. Degraded lands worth protecting: The biological importance of Southeast Asia's repeatedly logged forests. Proceedings of the Royal Society B: Biological Sciences 278(1702):82-90.

Edwards, D. P., Tobias, J. A., Sheil, D., Meijaard, E. and Laurance, W. F. 2014. Maintaining ecosystem function and services in logged tropical forests. Trends in Ecology \& Evolution 29(9):511-20.

Ellison, D., Morris, C. E., Locatelli, B. et al. 2017. Trees, forests and water: Cool insights for a hot world. Global Environmental Change 43:51-61.

Estrada, A., Garber, P. A., Rylands, A. B. et al. 2017. Impending extinction crisis of the world's primates: Why primates matter. Science Advances 3(1):e1600946. doi:10.1126/ sciadv.1600946.

FAO 2010. Global forest resources assessment 2010: Main report. FAO Forestry Paper 163. Rome: FAO.

FAO 2012. FRA 2015: Terms and definitions. Forest Resource Assessment Working Paper 180. Rome: FAO.

FAO 2015. Global forest resources assessment 2015: Desk reference. Rome: FAO. 
GAPKI (Gabungan Pengusaha Kelapa Sawit Indonesia) 2017. Refleksi Industri Kelapa Sawit 2016 and Prospek 2017. Available at: https://gapki.id/news/1848/refleksi-industri-kelapa-sawit2016-prospek-2017 (Accessed 27 July 2019).

Ghazoul, J. and Sheil, D. 2010. Tropical rain forest ecology, diversity, and conservation. New York: Oxford University Press.

Gibson, L., Lee, T. M., Koh, L. P. et al. 2011. Primary forests are irreplaceable for sustaining tropical biodiversity. Nature 478:378-81.

Global Forest Watch 2019. Forest monitoring designed for action. Available at: www .globalforestwatch.org (Accessed 26 January 2019).

Haken, J. 2011. Transnational crime in the developing world. Global Financial Integrity 12. Hill, C. M. 2015. Perspectives of 'conflict' at the wildlife-agriculture boundary: 10 years on. Human Dimensions of Wildlife 20(4):296-301.

Ilstedt, U., Tobella, A. B., Bazié, H. et al. 2016. Intermediate tree cover can maximize groundwater recharge in the seasonally dry tropics. Scientific Reports 6.

Inamdar, A., De Jode, H., Lindsay, K. and Cobb, S. 1999. Capitalizing on nature: protected area management. Science 283(5409):1856-7.

IPBES 2016. Summary for policymakers of the assessment report on pollinators, pollination and food production. Potts, S. G., Imperatriz-Fonseca, V. L., Ngo, H. T. et al. (eds.) Bonn, Germany: IPBES.

IPCC 2013. Climate change 2013: The physical science basis. Contribution of working group I to the fifth assessment report of the Intergovernmental Panel on Climate Change. Stocker, T. F., Qin, D., Plattner, G.-K. et al. (eds.) Cambridge: Cambridge University Press.

IUCN 2019. The IUCN red list of threatened species. Version 2018-2. Available at: www.iucnredlist .org (Accessed 26 January 2019).

IUCN and ITTO (International Tropical Timber Organization) 2019. Guidelines for the conservation and sustainable use of biodiversity in tropical timber production forests. Yokohama: ITTO And IUCN.

IUCN, UNEP and WWF 1980. World Conservation Strategy: Living Resource Conservation for Sustainable Development, Gland, Switzerland: IUCN.

Keenan, R. J., Reams, G. A., Achard, F. et al. 2015. Dynamics of global forest area: Results from the FAO Global Forest Resources Assessment 2015. Forest Ecology and Management 352:9-20.

Kissinger, G., Herold, M. and De Sy, V. 2012. Drivers of deforestation and forest degradation: A synthesis report for REDD+ Policymakers. Lexeme Consulting, Vancouver Canada, August 2012.

Kremen, C. 2015. Reframing the land-sparing/land-sharing debate for biodiversity conservation. Annals of the New York Academy of Sciences 1355(1):52-76.

Laurance, W. F., Clements, G. R., Sloan, S. et al. 2014. A global strategy for road building. Nature 513:229-32.

Laurance, W. F., Sayer, J. and Cassman, K. G. 2013. Agricultural expansion and its impacts on tropical nature. Trends in Ecology \& Evolution 29(2):107-16. 
Le Blanc, D. 2015. Towards integration at last? The Sustainable Development Goals as a network of targets. Sustainable Development 23:176-87.

Liswanti, N., Sheil, D., Basuki, I., Padmanaba, M. and Mulcahy, G. 2011. Falling back on forests: How forest-dwelling people cope with catastrophe in a changing landscape. The International Forestry Review 13(4):442-55.

Lobell, D. B., Schlenker, W. and Costa-Roberts, J. 2011. Climate trends and global crop production since 1980. Science 333:616-20.

MacDicken, K. G. 2015. Global Forest Resources Assessment 2015: What, why and how? Forest Ecology and Management 352:3-8.

Margono, B. A., Potapov, P. V., Turubanova, S., Stolle, F. and Hansen, M. C. 2014. Primary forest cover loss in Indonesia over 2000-2012. Nature Climate Change 4(8):730-5.

McCarthy, D. P., Donald, P. F., Scharlemann, J. P. W. et al. 2012. Financial costs of meeting global biodiversity conservation targets: Current spending and unmet needs. Science 338(6109):946-9.

McCarthy, J. F. and Robinson, K. 2016. Land, economic development, social justice and environmental management in Indonesia: The search for the people's sovereignty. In McCarthy, J. F. and Robinson, K. (eds.) Land and development in Indonesia: Searching for the people's sovereignty. Singapore: ISEAS-Yusof Ishak Institute, pp. 1-32.

Meijaard, E. and Sheil, D. 2007. A logged forest in Borneo is better than none at all. Nature 446:974.

Meijaard, E. and Sheil, D. 2008. The persistence and conservation of Borneo's mammals in lowland rain forests managed for timber: Observations, overviews and opportunities. Ecological Research 23:21-34.

Meijaard, E., Sheil, D., Nasi, R., et al. 2005. Life after logging: Reconciling wildlife conservation and production forestry in Indonesian Borneo. Bogor, Indonesia: CIFOR.

Melo, F. P., Arroyo-Rodríguez, V., Fahrig, L., Martínez-Ramos, M. and Tabarelli, M. 2013. On the hope for biodiversity-friendly tropical landscapes. Trends in Ecology \& Evolution 28(8):462-8.

Milner-Gulland, E. 2018. Documenting and tackling the illegal wildlife trade: Change and continuity over 40 years. Oryx 52(4):597-8.

Nater, A., Mattle-Greminger, M. P., Nurcahyo, A. et al. 2017. Morphometric, behavioral, and genomic evidence for a new orangutan species. Current Biology 27(22):3487-98.

Naughton-Treves, L., Alix-Garcia, J. and Chapman, C. A. 2011. Lessons about parks and poverty from a decade of forest loss and economic growth around Kibale National Park, Uganda. Proceedings of the National Academy of Sciences 108(34):13919-24.

Phalan, B., Onial, M., Balmford, A. and Green, R. E. 2011. Reconciling food production and biodiversity conservation: Land sharing and land sparing compared. Science 333:1289-91.

Pimm, S. L., Jenkins, C. N., Abell, R. et al. 2014. The biodiversity of species and their rates of extinction, distribution, and protection. Science 344(6187):1246752.

Putz, F. E., Zuidema, P. A., Synnott, T. et al. 2012. Sustaining conservation values in selectively logged tropical forests: The attained and the attainable. Conservation Letters 5(4):296-303.

Redford, K. H. 1992. The empty forest. BioScience 42(6):412-22. 
Ribot, J. C., Agrawal, A. and Larson, A. M. 2006. Recentralizing while decentralizing: How national governments reappropriate forest resources. World Development 34:1864-86.

Ricketts, T. H., Dinerstein, E., Boucher, T. et al. 2005. Pinpointing and preventing imminent extinctions. Proceedings of the National Academy of Sciences of the United States of America 102:18497-18501.

Robinson, B. E., Holland, M. B. and Naughton-Treves, L. 2014. Does secure land tenure save forests? A meta-analysis of the relationship between land tenure and tropical deforestation. Global Environmental Change 29:281-93.

Rodrigues, A. S., Akcakaya, H. R., Andelman, S. J. et al. 2004. Global gap analysis: Priority regions for expanding the global protected-area network. Bioscience 54:1092-1100.

Roe, D. 2008. The origins and evolution of the conservation-poverty debate: A review of key literature, events and policy processes. Oryx 42(04):491-503.

Rudel, T. K., Coomes, O. T., Moran, E. et al. 2005. Forest transitions: Towards a global understanding of land use change. Global Environmental Change 15(1):23-31.

Rudel, T. K., Defries, R., Asner, G. P. and Laurance, W. F. 2009. Changing drivers of deforestation and new opportunities for conservation. Conservation Biology 23(6):1396-405.

Sassen, M., Sheil, D., Giller, K. E. and Ter Braak, C. J. 2013. Complex contexts and dynamic drivers: Understanding four decades of forest loss and recovery in an East African protected area. Biological Conservation 159:257-68.

Sayer, J. and Cassman, K. G. 2013. Agricultural innovation to protect the environment. Proceedings of the National Academy of Sciences 110(21):8345-8.

Sayer, J. A. and Collins, M. 2012. Forest governance in a changing world: Reconciling local and global values. The Round Table 101:137-46.

Sayer, J. A., Maginnis, S. and Laurie, M. 2005. Forests in landscapes: Ecosystem approaches to sustainability. London and Sterling, VA: Earthscan and IUCN.

Sayer, J., Margules, C. and Boedhihartono, A. K. 2017. Will biodiversity be conserved in locallymanaged forests? Land 6(1):6.

Sayer, J., Sunderland, T., Ghazoul, J. et al. 2013. Ten principles for a landscape approach to reconciling agriculture, conservation, and other competing land uses. Proceedings of the National Academy of Sciences 110(21):8349-56.

Schipper, J., Chanson, J. S., Chiozza, F. et al. 2008. The status of the world's land and marine mammals: Diversity, threat, and knowledge. Science 322:225-30.

Scott, L. and McGill, A. 2018. From promise to reality: Does business really care about the SDGs? United Kingdom: Price Waterhouse Coopers.

Selwood, K. E., Mcgeoch, M. A. and Mac Nally, R. 2015. The effects of climate change and landuse change on demographic rates and population viability. Biological Reviews 90:837-53.

Sharpe, B. 1998. 'First the forest': Conservation, 'community' and 'participation' in south-west Cameroon. Africa 68(1):25-45.

Sheil, D. 2017. Exploring local perspectives and preferences in forest landscapes: Towards democratic conservation. In Sanz, N., Lewis, R. C., Mata, J. P. and Connaughton, C. (eds.) Tropical forest conservation: Long-term processes of human evolution, cultural adaptations and consumption patterns. Mexico City: Unesco, pp. 262-83. 
Sheil, D. 2018. Forests, atmospheric water and an uncertain future: The new biology of the global water cycle. Forest Ecosystems 5:1-22.

Sheil, D., Boissière, M. and Beaudoin, G. 2015. Unseen sentinels: Local monitoring and control in conservation's blind spots. Ecology and Society 20(2):39.

Sheil, D., Meijaard, E., Angelsen, A., Sayer, J. and Vanclay, J. K. 2013. Sharing future conservation costs. Science 339(6117):270-1.

Simula, M. 2008. Financing flows and needs to implement the non-legally binding instrument on all types of forests. Washington, DC: World Bank.

Sloan, S. and Sayer, J. A. 2015. Forest resources assessment of 2015 shows positive global trends but forest loss and degradation persist in poor tropical countries. Forest Ecology and Management 352:134-45.

Soga, M., Gaston, K., Koyanagi, T., Kurisu, K. and Hanaki, K. 2016. Urban residents' perceptions of neighbourhood nature: Does the extinction of experience matter? Biological Conservation 203:143-50.

Stafford-Smith, M., Griggs, D., Gaffney, O. et al. 2017. Integration: The key to implementing the Sustainable Development Goals. Sustainability Science 12:911-19.

Steffen, W., Broadgate, W., Deutsch, L., Gaffney, O. and Ludwig, C. 2015. The trajectory of the Anthropocene: The great acceleration. The Anthropocene Review 2(1):81-98.

Temudo, M. P. 2012. 'The white men bought the forests': Conservation and contestation in Guinea-Bissau, Western Africa. Conservation and Society 10(4):354-66.

Tittensor, D. P., Walpole, M., Hill, S. L. L., et al. 2014. A mid-term analysis of progress toward international biodiversity targets. Science 346(6202):241-4.

Tyrväinen, L., Pauleit, S., Seeland, K. and de Vries, S. 2005. Benefits and uses of urban forests and trees. In Konijnendijk, C., Nilsson, K., Randrup, T. and Schipperijn, J. (eds.) Urban Forests and Trees. Berlin: Springer, pp. 81-114.

Vira, B., Agarwal, B., Jamnadass, R. et al. 2015. Forests, trees and landscapes for food security and nutrition. In Vira, B., Wildburger, C. and Mansourian, S. (eds.) Forests and food: Addressing hunger and nutrition across sustainable landscapes. Cambridge: Open Book Publishers, pp. 9-27.

von Rintelen, K., Arida, E. and Häuser, C. 2017. A review of biodiversity-related issues and challenges in megadiverse Indonesia and other Southeast Asian countries. Research Ideas and Outcomes 3(1):e20860.

Waldron, A., Miller, D. C., Redding, D. et al. 2017. Reductions in global biodiversity loss predicted from conservation spending. Nature 551:364-7.

Warren, R., Vanderwal, J., Price, J. et al. 2013. Quantifying the benefit of early climate change mitigation in avoiding biodiversity loss. Nature Climate Change 3:678-82.

Watson, J. E., Dudley, N., Segan, D. B. and Hockings, M. 2014. The performance and potential of protected areas. Nature 515:67-73.

Watts, J. and Vidal, J. 2017. Environmental defenders being killed in record numbers globally, new research reveals. The Guardian (UK) 13 July. Available at: www.theguardian.com/ environment/2017/jul/13/environmental-defenders-being-killed-in-record-numbersglobally-new-research-reveals (Accessed 27 January 2019). 
Whiteman, A., Wickramasinghe, A. and Piña, L. 2015. Global trends in forest ownership, public income and expenditure on forestry and forestry employment. Forest Ecology and Management 352:99-108.

Wiens, J. J. 2016. Climate-related local extinctions are already widespread among plant and animal species. PLOS Biology 14(12):e2001104.

Wiersum, K. F. 1995. 200 years of sustainability in forestry: Lessons from history. Environmental Management 19:321-9.

Wrangham, R. 2002. Changing policy discourses and traditional communities. In Colfer, C. and Resosudarmo, D. A. P. (eds.) Which way forward? People, forests, and policymaking in Indonesia.

Washington, DC: Resources for the Future, Center for International Forestry Research (CIFOR) and Institute of Southeast Asian Studies (ISEAS), pp. 20-35.

Wright, S. J. and Muller-Landau, H. C. 2006. The uncertain future of tropical forest species. Biotropica 38(4):443-5. 